\title{
Orientation of Strategy of Private Universities under the Restructuring and Development of Sight
}

\author{
Changming Liu \\ liucm@yangtzeu.edu.cn
}

\begin{abstract}
Keywords: Restructuring and development; Private colleges and universities; School positioning; Research strategy

Abstract. In order to promote scientific orientation of Private Colleges and healthy development of literature research methods, must be put forward propositions private OF UNIVERSITY strategy research. 2015, China has 722 private colleges and universities, accounting for $28 \%$ of the country's colleges and universities, has become an important part of Chinese higher education. Orientation of Running Private Colleges in theoretical and strategic value, need to be clear research objectives, assumptions, ideas, methods, main content, scientific depth.
\end{abstract}

\section{Introduction}

Since the reform and opening up, China's higher education has been rapid development, in just three decades time, the threshold of the elite education popular education. In 1978, China's higher education gross enrollment rate of only $1.55 \%$ in 1988 to $3.7 \%$ in 1998 rose to $9.76 \%$. 1999 university enrollment, rapid increase in higher education enrollment rate in 2002 reached 15 percent, entered the popular stage [1] from elite education. In 2007 China's higher education gross enrollment rate of $23 \%$ in 2010, reaching $26.5 \%$ in 2012, reaching $30 \%$ in 2015 to reach $40 \%$ [2]. In the great development of higher education, private colleges also been a rapid development, as of May 21, 2015, there were 2553 colleges and universities, including private universities set up an independent 447, 275 independent colleges. Independent set of Private Universities and independent colleges collectively referred to as colleges and universities, both in total 722 , accounting for $28.3 \%$ of the total number of colleges and universities is an important part of the [3]Higher Education in China. Ministry of Education from 2013 began to put forward and implement the Regional College Applied Technology Universities to restructuring and development. Under the restructuring and development of Private Universities Sight how to determine its orientation, worthy of further study and reflection.

\section{Realistic Value Orientation of Private Universities}

Statement of Problem. June 28, 2013 the Ministry of Education held in Tianjin University of Applied Technology Transformation Development Research Centre (Institute) Union and local colleges and universities set up the forum, Vice Minister of Education Lu Xin pointed out that to promote the restructuring and development of local colleges and universities, is the current reform of higher education the development of an important era proposition [4]. April 2014 was held in Zhumadian "production Religions Development Strategy International Forum", around the "Chinese characteristics of the University of Applied Sciences" discussion [5]. "The Ministry of Education 2015 points" need to "start the reform, ordered some qualified guide, willingness of local colleges and universities transformation and development", "overall pilot universities can enter the pilot and to be part of the faculty or professional (cluster) enter the pilot. pilot should include private undergraduate colleges and independent colleges. "October 21, 2015, "Ministry of Education, the National Development and Reform Commission Ministry of Finance on the guide parts of the general guidance to the Universities of Applied transition (to teach Fa [2015] No. 7)" clearly requires that "all colleges and universities from around the adaptation and lead the development of new economic normality, service innovation-driven development of the overall situation, to strengthen the restructuring and development of the importance and urgency of understanding, in an 
important position in the current work, the spirit of reform and innovation, promote the transformation of the development part of regular undergraduate institutions . "[6]University of applied Sciences (College) Alliance chairman MENG proposed restructuring and development to reform and build a professional and professional groups as a breakthrough, in order to point to the construction of the University of applied Sciences. Provinces have introduced policies to promote local colleges and universities to the application of technology-based school restructuring and development. Thus, in the context of restructuring and development, private colleges how orientation, worthy of further study.

Definition Study. Transformation of Development of Private Universities Running positioned at Horizon Research, defined within the following ranges:

Restructuring and development: "The Ministry of Education guidance on the restructuring and development of local Universities (draft)" clearly proposed to "guide and promote the restructuring and development of some local Universities to application technology type Universities", "Ministry of Education 2016 points" and proposed "to promote private education classification reform"; "encourage qualified regular undergraduate institutions to apply transformation, intensify support orderly conduct reform, together with the relevant departments to establish follow-up examination and evaluation system." Therefore, this study is the restructuring and development of keywords, study the positioning of Private Universities should also discuss under the restructuring and development background.

Private Universities: Private Colleges refers to non-governmental organizations and individuals, the use of non-education budget, and the community of independent operation and management of colleges and universities to provide alternative education services. 2013 revised "People's Republic of China Private Education Promotion Law" Article III, private education belongs to public welfare, is an integral part of socialist education. State practices actively encourage, support, correct guidance, according to the management policy of private education. Governments at all levels should be private education into the national economic and social development plan. A specific object of this research project is being developed by the independent Institute of restructuring public education institutions turn to private colleges and universities.

Manage orientation: refers to the school's needs and according to the environment in the school of social and political, economic and cultural development, from the current situation of the school and school conditions, to determine the direction of school development, goals, and focus on building school level, type, model and characteristics and so on. The research is in the process of conversion turn set strategy and positioning of Running Private Colleges issue.

Significance. This study has important theoretical significance:

First, help to correct the cognitive restructuring of Private Colleges and Universities turn set a clear strategic position and running a profound impact on positioning and promoting faculty and school were widely established educational concept positioning, the positioning of School and formed a good situation work together to seek common development.

Second, it helps correct understanding of the orientation of running objective and subjective constraints realistic conditions, develop appropriate national economy, social development and cultural heritage need for school-based running its own conditions and positioning.

Third, it helps clear the implementation of strategies and measures targeting schools, colleges and universities to promote the unique, do a level, do the benefits.

\section{Theoretical Private Universities Running Position}

Orientation of Running Research Status. In "Running Orientation" in China known as keywords to search the Internet received 641 relevant literature. Search found the United States, Russia and military institutions to demand-oriented combination of inheritance and innovation, the school considered an act of positioning mode institutions, enlightening; the British after World War II created 34 to meet the needs of the world economy and technological development polytechnics, opened the higher education "Dual" era, effectively promoting the popularization of the UK higher education process. Although polytechnics existed for only 20 years time, but the local application of 
the Orientation of Running worth our reference. German vocational colleges in the long-term development and exploration, the formation of economic development in line with national or regional positioning mode, with reference value. Orientation of Universities in China began in the 1990s, educators Pan Maoyuan that "social division of labor, is the type of division of colleges and universities, according to the final positioning of the positioning and development of colleges and universities, must follow the law of education and social development of relations" [7]. Jiangxi Normal Sui Ivan believes that philosophy is University as university presidents hope to accomplishing the university an educational idea of what is the direction of the university in respect of their own with a strong subjective color choices they hold, roles, where the characteristics of University of ideals and values to pursue. [8] Wuhan University Huang Jingyi think, school targeting institutions of higher learning, colleges and universities is a strategic position and direction make the future economic and social development and the entire higher education system in the strategic choice[9]. In essence, the positioning school is an idea, a concept, in particular, it is the governance of the school to university who want an educational philosophy accomplishing what it was like, it relates to the direction of the university selection, orientation and educational role characteristics and other aspects related to the various functions into full play schools, colleges and universities is the key to an ability to achieve comprehensive, coordinated and sustainable development, is the fundamental characteristic university education and the formation of. Yangzhou University Disciplines proposed school is a localization of the university system includes many projects, but it is also a dynamic development of the system. Including social services-oriented positioning, development targeting, Type Orientation, Training Standards for positioning, school size and level of targeting, positioning, and other school characteristics. Songda Cheng pointed out that, when establishing educational goals orientation, attention should be pragmatic, forward-looking, accuracy requirements. Running Orientation and fly forward-looking think, conditionality and stability of the three characteristics, targeting school should follow the principle of reality may be, the overall principle of optimization and development advantages of combining the principles of sustainable development.

Orientation of Running the Theoretical Basis. Running general theory of localization. School Reform in Higher Education is positioned to adapt to the inevitable socialist market economic system, but also social needs schools Universities for the exercise of autonomy. Who is running the main target is it? Who is this related to school autonomy exercised by Yes. First organized by the school district and the concept will be separated. Organizers investors have ownership of school property, the school is run by school administrators. Positioning to the school principal is the school, rather than the organizers, in general, the school must have its own unique educational ideology, but also consider the wishes of investors.

Theory of comparative advantage. Originated from the theory of comparative advantage $\bullet$ David Ricardo, Adam Smith • absolute cost theory criticism. - Adam Smith believed in international trade, trade both sides can use their products have absolute cost advantage enchant does not have absolute cost advantages of the products, and thus profit from each other. Theory of comparative advantage not only for the business analysis of the use of scarce resources in the production of all economic activity, are instructive. Economist Lin Yifu think the principle of comparative advantage applies not only between different national economies, for different regions within a country, regional development between different enterprises, economic development entities also apply. Universities as an economic entity, comparative advantage theory the feasibility of its application, the school is to be positioned in the comparison basis, established as an invaluable; inventory of resources, mining advantages; build dynamic comparative advantage in development.

\section{Orientation of Running Private Universities Research Strategy}

Research Objectives. Research objectives of this project are: to recognize the restructuring turn set the objective and subjective conditions of the environment in the process of private undergraduate colleges and universities face, clear thinking, and basic principles to guide the Orientation of Running Private Universities proposed Running Orientation private undergraduate colleges on the 
basis of That is for positioning, targeting, positioning type, personnel training specifications location, orientation and school characteristics school level positioning.

Hypothesis. Assumption 1: local, regional and industry economic and social development needs of applied talents is the service-oriented private undergraduate colleges;

Assumption 2: Cultivation of going down, the lingua franca, retain technical talent is practical educational goals private undergraduate colleges;

Assumption 3: application type, technology, practical basic types of Private Universities in Running Schools.

Research Ideas. First, literature search, collect local colleges, private colleges and independent colleges Orientation of literature, screening can learn from reading the information, you can refer to figure out the content, then the orientation of running preconditions and analysis of subjective factors in the learning and the basis of comparison of similar Academies Orientation program, proposed to the University of Engineering and technology Yangtze case geopositioning school guiding ideology and basic principles, each study and propose educational alarms, formed private undergraduate programs under the Higher Education geopositioning transition sight.

Research Methods. According to research needs, this project will use a method under study:

Literature research, a large collection, screening the existing literature on local colleges, independent colleges and private schools targeting universities, selected reference value of literature, research-based reference information.

Case study, engineering technology, Yangtze University as a case study, carried out for the school, the strategic objectives, personnel training specifications, type and level of school, school characteristics and school effectiveness research targeting attributes.

Comparative research, select and Orientation Programme Yangtze University College of Engineering and Technology similar independent colleges and private colleges and universities, their comparison, analysis of its characteristics, which summed up can learn from the experience of the present research provides reference materials and research ideas.

Research Content. Main research content:

First, the prerequisite of Running positioned so that the country's economic, social and cultural development of university personnel training and the objective needs of the development trend of research, the school's own educational resources, experience, characteristics studied.

Second, the guiding ideology and basic principles of educational research orientation.

Third, the body positioning research school, that school service-oriented positioning research, educational objective orientation, school type Orientation, Training Standards for research, educational level and school characteristics research, school effectiveness research property.

Fourth, the implementation of the Strategy of Running targeting.

\section{References}

[1] Information on http://baike.baidu.com

[2] Information on http://www.china.com.cn

[3] Information onhttp://www.canghe.edu.cn

[4] Information on http://www.auas.org.cn

[5] Reporter. Many colleges and universities issued a "consensus Zhumadian" to promote the restructuring and development of local colleges and universities. China Education Daily. April $28,2014$.

[6] C.M.Liu :Transition sleepy and Countermeasures Value Orientation of Local Universities under the Background.Development of the Yangtze University Social Science Edition,(2016)N0.1

[7] M.Y.Pan andM.Wu: Classification and Localization of Universities . Education Forum, by the end of 20031, Vol.3(2003)N0.3,p5-9 
[8] Sui Ivan. Orientation of Running University Idea and governance of the school [J]. Higher Education Research,( 2001)N0.4,p49-52

[9]X.J. Liu:On Higher Schools [J]. Higher Education Research. 2003 (1)

[10] D.Xian:Higher positioning.competition choice.Pekingese Education Reviews.(2004)N04. 